\title{
Mercury and methylmercury in carapace of the marine turtle Caretta caretta, in northeastern Brazil and its potential for environmental monitoring
}

\author{
CÉSAR AUGUSTO B. RODRIGUEZ ${ }^{1}$, MOISES F. BEZERRA ${ }^{2}$, CARLOS EDUARDO \\ DE REZENDE ${ }^{3}$, WANDERLEY R. BASTOS ${ }^{4}$ and LUIZ D. DE LACERDA ${ }^{1}$
}

${ }^{1}$ Laboratório de Biogeoquímica Costeira, Instituto de Ciências do Mar, Universidade Federal do Ceará, Av. Abolição, 3207, 60165-081 Fortaleza, CE, Brazil

${ }^{2}$ Department of Biology, San Diego State University, 92182-4614, San Diego, CA, USA

${ }^{3}$ Laboratório de Ciências Ambientais, Centro de Biociências e Biotecnologia, Universidade Estadual do Norte Fluminense

Darcy Ribeiro, Av. Alberto Lamego, 2000, Parque California, 28013-602 Campos dos Goytacazes, RJ, Brazil

${ }^{4}$ Regional Development and Environment Postgraduate Program, Environmental Biogeochemistry Wolfgang C. Pfeiffer, Rondônia Federal University, Av. Pres. Dutra, 2967, Olaria, 76801-059 Porto Velho, RO, Brazil

Manuscript received on July 2, 2018; accepted for publication on October 30, 2018

How to cite: RODRIGUEZ CAB, BEZERRA MF, REZENDE CE, BASTOS WR AND LACERDA LD. 2019. Mercury and methylmercury in carapace of the marine turtle Caretta caretta, in northeastern Brazil and its potential for environmental monitoring. An Acad Bras Cienc 91: e20180672. DOI 10.1590/0001-3765201920180672.

\begin{abstract}
The present work tests the use of carapace fragments of the marine turtle Caretta caretta as a tool for environmental biomonitoring of mercury $(\mathrm{Hg})$ and to evaluate the influence of biological and ecological factors in $\mathrm{Hg}$ concentrations. Samples of carapace fragments were obtained during the nesting season of 2012 and 2016 and were analyzed for their total-Hg and methyl-Hg concentrations and the isotopic composition of carbon and nitrogen $\left(\delta^{15} \mathrm{~N}\right.$ and $\left.\delta^{13} \mathrm{C}\right)$. Seventy-six females were sampled, with an average size of 87.1 to $107 \mathrm{~cm}$ of curved carapace length (CCL). The results showed a wide variation in total $\mathrm{Hg}$ concentrations (3.3 - 1,672 ng g-1) and low concentrations of methyl-Hg, not showing any pattern of accumulation among the individuals. The isotopic composition of $\delta^{15} \mathrm{~N}$ and $\delta^{13} \mathrm{C}$ suggests that the individuals sampled belong to a high trophic level but did not present any relationship with the $\mathrm{Hg}$ concentrations. It suggests that, at least with the existing results, and unlike other turtle species, carapace fragments of $\mathrm{C}$. caretta cannot yet be used in environmental monitoring.
\end{abstract}

Key words: Caretta caretta, mercury, carapace, methylmercury, stable isotopes.

\section{INTRODUCTION}

The long residence time of mercury $(\mathrm{Hg})$ in the oceans (approximately 30 years) and the high toxicity of its organic form (i.e. methyl-Hg) make particularly important to study $\mathrm{Hg}$ distribution in marine species (UNEP 2013).

Correspondence to: César Augusto Barrios Rodriguez

E-mail: hpbarrios15@gmail.com

ORCid: https://orcid.org/0000-0003-4086-835X
Sea turtles and other marine organisms are mainly exposed to $\mathrm{Hg}$ through dietary routes (Schneider et al. 2013) where methyl-Hg is strongly bond to fat molecules and is readily absorbed in the digestive tract of these animals (Lacerda and Malm 2008). The methyl-Hg strong affinity to lipids results in slow elimination rates, compared to $\mathrm{Hg}$ inorganic forms (e.g. $\mathrm{Hg}^{2+}$ and $\mathrm{Hg}^{0}$ ), contributing to overall accumulation throughout the organism lifetime (Bisinoti and Jardim 2004, Lacerda and 
Malm 2008). Methyl-Hg is highly poisonous and the toxicity varies according to the intake path, exposure amount, and individual susceptibility (Hong et al. 2012). The main target for methyl$\mathrm{Hg}$ toxicity is the central nervous system, where it alters the biochemical and ultrastructural machinery of both astrocytes and neurons (Shanker et al. 2003). However, $\mathrm{Hg}$ accumulation and concentration patterns may vary among species depending on trophic level, habitat and the life span (Kidd et al. 1995). Mercury can undergo biomagnification through the food chain, resulting in higher concentrations and exposure in species at higher trophic levels (Camacho et al. 2013), with exposure effects modulated by demographic traits (e.g. age, sex, habitat), metabolic responses and availability (Pugh and Becker 2001).

Marine organisms present some mechanisms of metal removal. Aquatic reptiles are known to reduce contaminant burdens by the maternal transfer of essential and non-essential elements to eggs (Ehsanpour et al. 2014). This mechanism is thought to explain in part the wide range of $\mathrm{Hg}$ contamination observed in hawksbill turtles, Eretmochelys imbricata (Ehsanpour et al. 2014) and differences in $\mathrm{Hg}$ accumulation between males and females specimens of the same species (Meyers-Schöne and Walton 1994). However, as the biochemistry of $\mathrm{Hg}$ in marine turtles is not fully understood, it makes more challenging their use in environmental monitoring efforts (Sakai et al. 1995, Guirlet et al. 2008).

All sea turtle species are listed in different risk categories within the IUCN Red List (2018), therefore it is important to develop non-invasive monitoring methods for toxic metals, such as $\mathrm{Hg}$ (Hopkins et al. 2013). One of these methods is the use of keratinized structures composing the turtle's carapace, skin and nails. The high amino acid content in keratin increases $\mathrm{Hg}$ binding capacity and results in its immobilization in the metabolic stable keratin layers, which can further be assessed for $\mathrm{Hg}$ exposure over time (Toni et al. 2007, Schneider et al. 2015).

Among the seven species of marine turtles, loggerhead turtles (Caretta caretta) and green turtle (Chelonia mydas) are the most used species for this monitoring approach. In $C$. caretta, carapace fragments (i.e. scutes) have been shown as reliable tissues to monitor $\mathrm{Hg}$ exposure either in the whole body burden (Sakai et al. 2000) and in internal tissues (Day et al. 2005). Recently, Casini et al. (2018), not found a statistically significant correlation between $\mathrm{Hg}$ concentrations in carapace fragments and body size in individuals of $C$. caretta from the Mediterranean Sea, probably due to the low number $(n=3)$ of specimens. In contrast, scutes of the green turtle C. mydas, were found to reflect $\mathrm{Hg}$ concentrations of internal organs (Bezerra et al. 2013) and variated with size class and habitatspecific $\mathrm{Hg}$ backgrounds which was associated to Hg content in the turtle's diet (Bezerra et al. 2012, 2015).

Since no data existed, so far, on $\mathrm{Hg}$ concentrations in the South Atlantic population of the loggerhead turtle $C$. caretta, we sampled a large number of individuals to quantify the total-Hg and methyl-Hg contents in carapace fragments and the influence of biological and ecological factors in $\mathrm{Hg}$ concentrations, as a first step to evaluate scutes as a tool for environmental $\mathrm{Hg}$ monitoring and individual exposure to this pollutant.

\section{MATERIALS AND METHODS}

All procedures and analyzes of this work were carried out within the current norms of Brazilian environmental legislation, carried out under the authorization of the System of Authorization and Information in Biodiversity - SISBIO, License No. 21693-9 (2016).

This study was conducted along the coastal zone of Bahia state, the largest nesting area of loggerhead turtles in Brazil (Marcovaldi et al. 
2010). Scutes samples were obtained from mature females specimens found nesting at the beach of Praia do Forte, Sauípe and Busca Vida, Bahia localities (Fig. 1) during nesting seasons of 2012 and 2016. Carapace fragments were collected from 76 adult females, which were classified as adult ( $\mathrm{n}=72$ ) and subadult $(\mathrm{n}=4)$, according to their size categories following Dodd (1988) categories. Nesting females were momentarily restrained in situ after laying and covering the eggs in order to measure (e.g. curved carapace length (CCL) and curved carapace width $(\mathrm{CCW}))$ and to collect carapace fragments that were loose or falling off due to barnacle incrustations. The Brazilian Marine Turtle Conservation Program (TAMAR) keeps a detailed inventory of the females that come to nest in Praia do Forte and nearby areas by tagging all nesting individuals, which makes possible to classify them as first-time nester or remigrants.

\section{TOTAL AND METHYL Hg QUANTIFICATION}

Quantification procedure of total-Hg in biological samples followed Bezerra et al. (2012). In summary, samples of $0.5 \mathrm{~g}$ in dry mass were placed in duplicate in Teflon tubes containing $10 \mathrm{~mL}$ of concentrated nitric acid $\left(\mathrm{HNO}_{3} 65 \%\right)$ for onehour pre-digestion. Digestion was carried out in a microwave oven, $800 \mathrm{~W}$ at $200^{\circ} \mathrm{C}$ for $30 \mathrm{~min}$. After cooling, $1 \mathrm{~mL}$ of hydrogen peroxide $\left(\mathrm{H}_{2} \mathrm{O}_{2}\right)$ was added. The final extract was transferred and diluted in volumetric flasks to $100 \mathrm{~mL}$. $\mathrm{Hg}$ concentrations were quantified by cold vapor atomic absorption spectrophotometer CV-ASS), in a NIC RA-3 (NIPPON $\left.{ }^{\circledR}\right)$ spectrophotometer. Instrument calibration was performed using solutions with known $\mathrm{Hg}$ concentrations varying from 0.0 to 5.0 $\mathrm{ng} \mathrm{g}^{-1}$. The average detection limit (LD) of the method was $0.08 \pm 0.08 \mathrm{ng} \mathrm{g}^{-1}$ calculated as three times the standard deviation of reagent blanks

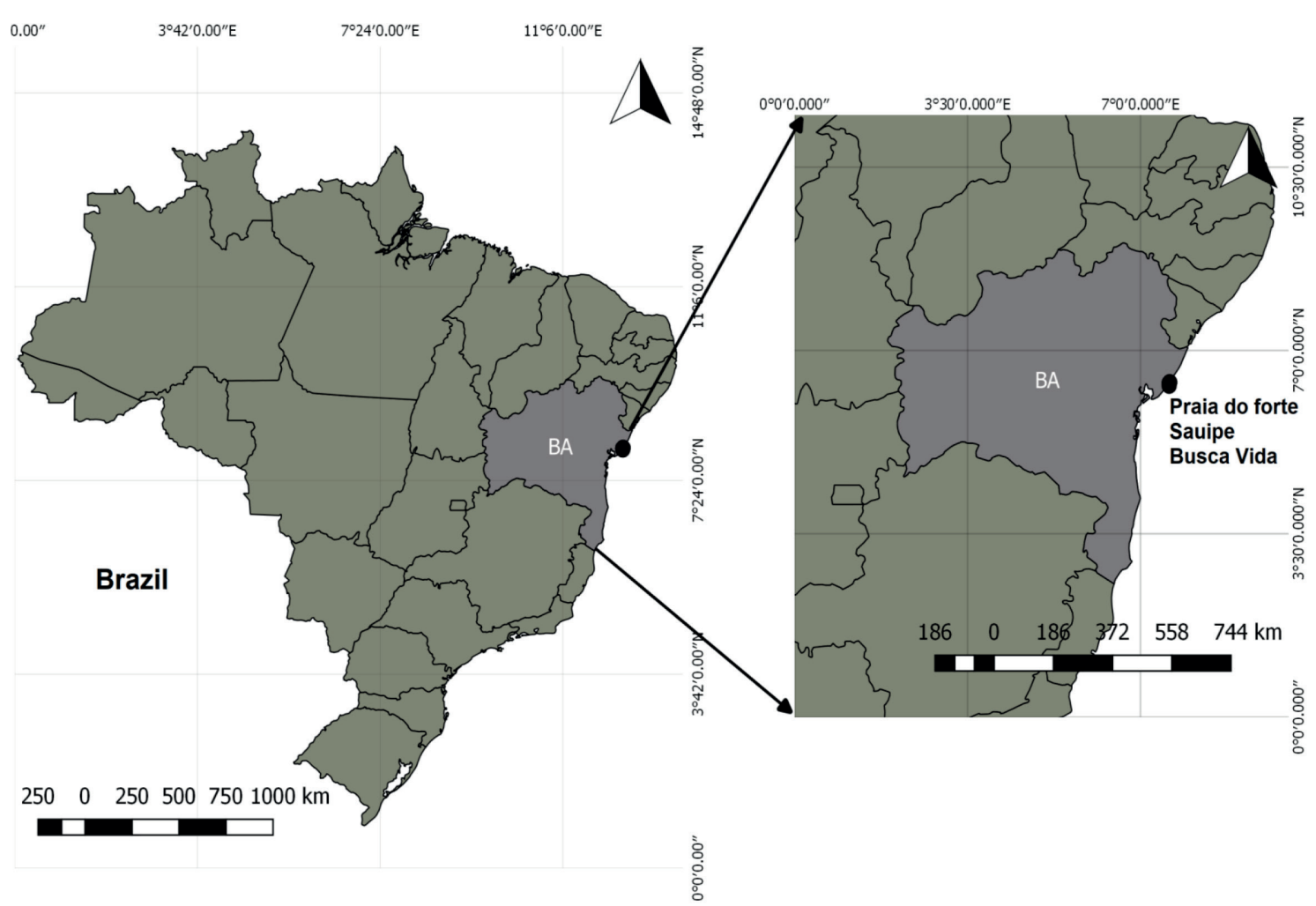

Figure 1 - Study area on the coast of the state of Bahia (Praia do Forte) in NE Brazil. Point black represent the location of female turtles spotted nesting. 
divided by the inclination of the calibration curve (US EPA 2000). The validation of the methodology was obtained by using certified reference materials (SRM), mussel tissue (ERM-CE278K) and lobster hepatopancreas (TORT-2), with recovery values of $93 \%$ and $100 \%$ respectively.

For methyl-Hg quantifications, approximately $200 \mathrm{mg}$ of carapace fragments was weighed in PTFE tube and $5.0 \mathrm{~mL}$ of $25 \% \mathrm{KOH}$ methanolic solution was used to extract methyl-Hg in an oven at $70^{\circ}$.C for $6 \mathrm{~h}$ with gentle stirring every hour; the samples were then kept in the dark to avoid possible degradation of methyl-Hg. Subsequently, the ethylation process was done with $300 \mu \mathrm{L}$ of $2 \mathrm{~mol} / \mathrm{L}$ acetate buffer $(\mathrm{pH} 4.5$ ) followed by the addition of $30 \mu \mathrm{L}$ of sample and $50 \mu \mathrm{L}$ of tetra ethyl sodium borate (1\%) according to Taylor et al. (2011). The final volume was brought to 40 $\mathrm{mL}$ with ultra-pure water (milli-Q, Millipore, Cambridge, MA, USA) and analyzed on a MERXTM automated methyl mercury system from Brooks Rand Labs (Seattle, USA) coupled an atomic fluorescence spectrophotometer. Precision and accuracy of methyl-Hg determinations were ensured by the use of duplicate analyses of samples and certified reference materials, Tuna Fish - BCR463 and Dorm-2 - NRC, was run with each batch of samples with a mean recovery of $96 \%$ e $85 \%$ for methyl-Hg determination, respectively. Limits of detection (LD) and quantification (LQ) for methyl$\mathrm{Hg}$ determinations were $0,003 \mathrm{mg} \mathrm{kg}^{-1}$ and 0,009 mg. $\mathrm{kg}^{-1}$, respectively (CITAC 2002).

\section{NITROGEN AND CARBON STABLE ISOTOPES $\left(\delta^{15} \mathrm{~N}\right.$} AND $\left.\delta^{13} \mathrm{C}\right)$

Approximately $1 \mathrm{mg}$ of dry sample which was weighed in tin capsules and analyzed on an elemental analyzer (Flash 2000) coupled to a continuous flow mass spectrometer (Isotope Ratio Mass Spectrometry - IRMS, Delta V Advantage, Thermo Scientific, Germany). All results are expressed as delta value $(\delta)$, Pee Dee Belemnite notation for $\delta^{13} \mathrm{C}$ in parts per thousand (\%) and atmospheric $\mathrm{N}_{2}$ for $\delta^{15} \mathrm{~N}$, according to (Peterson and Fry 1987). The analytical replicates showed variations lower than $5 \%$ and the accuracy was determined from a certified standard of protein (B2155) and the results showed $97 \pm 1 \%$.

\section{STATISTICS}

The Shapiro Wilk test was used to evaluate the normality of the data. Non-parametric Spearman's correlation was used to evaluate the relationship between biometric data and concentrations of total-Hg and methyl-Hg and Mann-Whitney test was used to compare total-Hg between remigrant turtles and those nesting for the first time. Pearson's correlation was applied to evaluate the relationship between CCL and CCW. Student's t-test was used to compare size between the same turtle's groups. The relationships between the $\delta^{13} \mathrm{C}$ and $\delta^{15} \mathrm{~N}$ values and the concentrations of total$\mathrm{Hg}$ and methyl-Hg were determined from linear regressions. Outliers, which totaled three (3) in our samples were removed for a better interpretation of the graphics. The significance level used for the tests was 95\% ( $<<0.05)$. Statistical tests and graphing were performed using RStudio software (version 0.98.976 - C RStudio, Inc. 2009-2013 and Microsoft Office 365).

\section{RESULTS}

Carapace fragments were collected from 76 adult females ranging from 87.1 to $107 \mathrm{~cm}$ of CCL (mean of $98.5 \pm 5 \mathrm{~cm}$ ) and 79.6 to $98.9 \mathrm{~cm}$ of CCW (mean of $88.9 \pm 4 \mathrm{~cm}$ ). Thirty-nine females were identified as remigrants while 29 females were nesting at the location for the first time (Table I). Information were missing for eight specimens. A significant correlation was observed (Pearson's $r=0.76, p<$ 0.05) between CCL and CCW (Fig. 2). When comparing the CCL of the groups of remigrant 


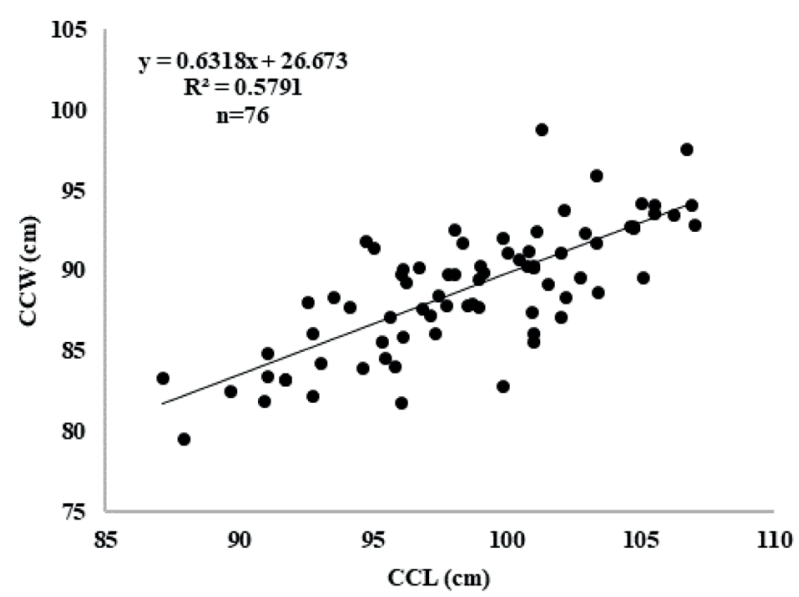

Figure 2 - Relationship between the Curved Carapace Length (CCL) and the Curved Carapace Width (CCW).

turtles and those arriving for the first time, no significant difference was found (Student's t-test; $\mathrm{p}>0.05)$. The first-time nesting turtles showed an average of $98 \pm 4 \mathrm{~cm}$ of CCL, while remigrant turtles presented an average of $98 \pm 5 \mathrm{~cm}$ of CCL. Average concentrations of total- $\mathrm{Hg}$, methyl- $\mathrm{Hg}$, $\delta^{13} \mathrm{C}$ and $\delta^{15} \mathrm{~N}$ isotopes and nesting status are also presented in Table I. Individual results for each animal are detailed in the supplementary material (Table SI).

The concentrations of total-Hg in the carapace fragments of the 76 animals showed a wide variability, even though the individuals studied showed similar morphological, physiological and migratory traits. The observed concentrations varied from $3.3 \mathrm{ng} \mathrm{g}^{-1}$ to $2,169 \mathrm{ng} \mathrm{g}^{-1}$, with a mean of 183.6 $\pm 326 \mathrm{ng} \mathrm{g}^{-1}$ (Table I). Methyl-Hg concentrations in carapace fragments of 15 adult females, varying in size from of 89.6 to $107 \mathrm{~cm}$. average of $99 \pm 4$ $\mathrm{cm}$, being 12 categorized as remigrants and 3 as first-time arrivals, varied from $0.2 \mathrm{ng} \mathrm{g}^{-1}$ to $55.2 \mathrm{ng}$ $\mathrm{g}^{-1}$, with a mean of $11.9 \pm 15 \mathrm{ng} \mathrm{g}^{-1}$ (Table I). The percentage of methyl- $\mathrm{Hg}$ relative to total- $\mathrm{Hg}$ varied from 0.5 to $32.6 \%$, with an average of $10.7 \pm 10 \%$.

No correlation was found (Spearman's $r=0.28$, $\mathrm{p}>0.05$ ) between total-Hg levels and CCL (Fig. 3). According to the nesting status, the remigrant individuals showed a concentration varying from $3.3 \mathrm{ng} \mathrm{g}^{-1}$ to $1,672 \mathrm{ng} \mathrm{g}^{-1}$, with a mean of $142 \pm$ $270 \mathrm{ng} \mathrm{g}^{-1}$, while the turtles that arrived for the first time had $\mathrm{Hg}$ concentrations ranging from $3.8 \mathrm{ng} \mathrm{g}^{-1}$ to $835 \mathrm{ng} \mathrm{g}^{-1}$, with a median of $165 \pm 188 \mathrm{ng} \mathrm{g}^{-1}$. The comparison between the total-Hg content in the remigrants populations and those that arrived for the first time showed no significant difference (Mann Whitney's $U=681.5$; $\mathrm{p}>0.05$ ).

The correlation between methyl-Hg concentrations with CCL, and \% methyl-Hg with CCL, were not significant $(r=0.27, r=-0.14)$. The concentrations of methyl-Hg in the migratory turtles $(\mathrm{n}=8)$ ranged from 0.19 to $8.3 \mathrm{ng} \mathrm{g}^{-1}$, with a mean of $4.0 \pm 3.1 \mathrm{ng} \mathrm{g}^{-1}$, whereas in the first-time turtles $(n=3)$, the concentrations ranged from 2.9 to $18.2 \mathrm{ng} \mathrm{g}^{-1}$, with a mean of $9.9 \pm 7.3 \mathrm{ng} \mathrm{g}^{-1}$. There was no significant difference between the methyl$\mathrm{Hg}$ concentrations between remigrants turtles and those that arrived for the first time (Mann Whitney's $\mathrm{U}=21 ; \mathrm{p}>0.05)$.

Isotope determination was performed in nine individuals, all of whom had their measured total-Hg concentrations, but only 4 had quantified methyl-Hg concentrations (Table I). The $\delta^{13} \mathrm{C}$ and $\delta^{15} \mathrm{~N}$ presented a mean of $-16.7 \pm 1.0 \%$ o $(-18.8$ to $-15.6 \%$ ) and of $7.4 \pm 2.1 \%$ (5.7 to $11.9 \%$ ), respectively. The size of the individuals used in these analyzes varied from 94 to $104 \mathrm{~cm}$ with an average of $99 \pm 3.12 \mathrm{~cm}$. The relationship between $\delta^{13} \mathrm{C}$ and $\delta^{15} \mathrm{~N}$ showed that the nine turtles had similarities in their diet. Seven turtles showed values of $\delta^{13} \mathrm{C}$ and $\delta^{15} \mathrm{~N}$ in the range of -17.0 to $-15.5 \%$, and 5.7 to $7.6 \%$ respectively; while the other two turtles presented a higher enrichment of $\delta^{15} \mathrm{~N}$, with values of $9.8 \%$ to $11.9 \%$ and values of $\delta^{13} \mathrm{C}$ from -18.8 to $-17.6 \%$. No correlation was observed between $\delta^{15} \mathrm{~N}$ and total $\mathrm{Hg}$ (Spearman's $\mathrm{r}$ $=0.66 ; \mathrm{p}>0.05)$. 
TABLE I

Size $(\mathrm{n}=76)$, total-Hg $(\mathrm{n}=76)$, Methyl-Hg $(\mathrm{n}=15), \%$ Methyl-Hg $(\mathrm{n}=15), \delta^{13} \mathrm{C}(\mathrm{n}=9)$ and $\delta{ }^{15} \mathrm{~N}(\mathrm{n}=9)$ concentrations of nesting loggerhead turtles from Sauipe, Busca Vida and Praia do Forte.

\begin{tabular}{|c|c|c|c|c|c|c|c|}
\hline & CCL $(\mathrm{cm})$ & $\mathrm{CCW}(\mathrm{cm})$ & Total-Hg (ng g $\left.{ }^{-1}\right)$ & Methyl-Hg (ng g $\left.{ }^{-1}\right)$ & \%Methyl-Hg & $\delta^{13} \mathrm{C}$ & $\delta^{15} \mathbf{N}$ \\
\hline Mean & 98.5 & 88.9 & 183.6 & 11.9 & 10.7 & -16.7 & 7.4 \\
\hline SD & 5 & 4 & 326 & 8 & 6 & 5 & 2 \\
\hline Min & 87.1 & 79.6 & 3.3 & 0.2 & 0.5 & 18.8 & 5.7 \\
\hline Max & 107 & 98.9 & 2,169 & 55.2 & 32.6 & 15.6 & 11.9 \\
\hline
\end{tabular}

SD: Standard deviation.

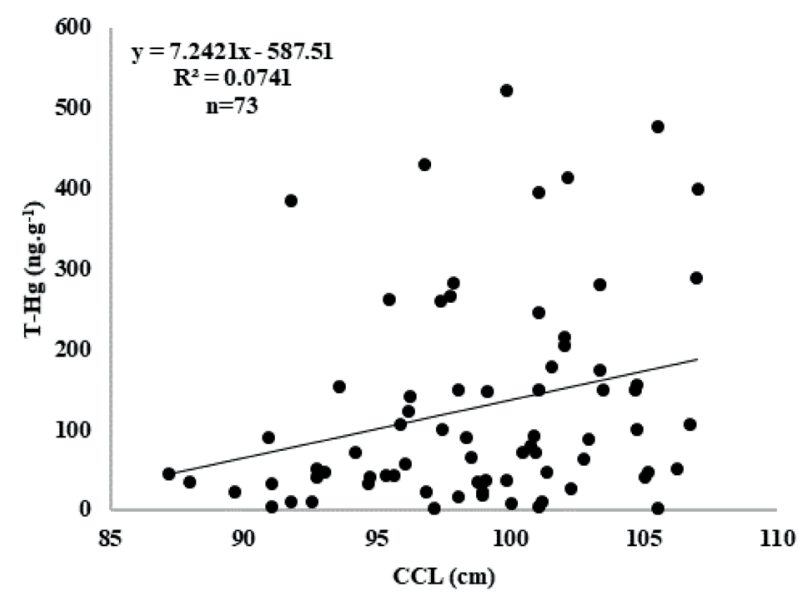

Figure 3 - Relationship between $\mathrm{T}-\mathrm{Hg}$ concentration and Curved Carapace Length (CCL) in the population of females of loggerhead turtles.

\section{DISCUSSION}

We present here the first account of total- $\mathrm{Hg}$ and methyl-Hg distribution in a $C$. caretta population from the South Atlantic. With our dataset composed exclusively of nesting females categorized as remigrants female and first-time nesting females, it was possible to evaluate the effect of maternal metal offloading between these two groups. However, the comparison of the $\mathrm{Hg}$ concentration for the two groups did not show a significant difference, as it is mentioned by different works, which have shown a low maternal transfer rate of toxic metals like $\mathrm{Hg}$, in comparison with essential metals like $\mathrm{Zn}$, $\mathrm{Cu}$ or Se (Guirlet et al. 2008, Bergeron et al. 2010, Hopkins et al. 2013).

One of the main routes of $\mathrm{Hg}$ exposure in marine organisms is the diet (Mackay and Fraser 2000, Gray 2002), which often varies with life- stage. Therefore, organisms' ecological niche and feeding habitats are two major factors controlling $\mathrm{Hg}$ concentrations. Our results with loggerhead turtles are an example of that $C$. caretta, feeds opportunistically and consumes a wide variety of food items (Tomas et al. 2001, Frick et al. 2009). Such variable diet and the feeding frequency directly affect $\mathrm{Hg}$ incorporation.

In the early and juvenile stages, loggerhead turtles are epipelagic inhabiting oceanic zones and feeding most of the time in the first five meters of the water column. As sub-adults and adults they become neritic feeding mainly on the bottom (Bolten 2003). The change in feeding habitat and diet may lead to differences in the exposure level to $\mathrm{Hg}$ as shown in juvenile and adult specimens of $C$. mydas (Bezerra et al. 2012). However, the sample presented here is composed mostly of adults and, thus, with similar diets. Loggerhead turtles larger than $50 \mathrm{~cm}$ change their distribution from oceanic zones to coastal zones, where they feed mainly on benthic animals (Bjorndal 1997). In this context, assuming no significant differences in diet for these adults, and with feeding being the major form of $\mathrm{Hg}$ intake, one would expect a smaller range of $\mathrm{Hg}$ concentrations than that found in this study. However, despite their comparable size as adults, the concentrations varied from 3.8 up to $1,672 \mathrm{ng}$ $\mathrm{g}^{-1}$.

There are few studies reporting on total- $\mathrm{Hg}$ concentrations in carapace fragments of $C$. caretta. Day et al. (2005) reported similar concentrations 
to the Bahia turtles in 34 individuals of loggerhead turtle, with similar sizes $(50-95 \mathrm{~cm})$ to those used in the present work, in the southeastern coast of the United States, where $\mathrm{Hg}$ concentrations varying from $62-2,837 \mathrm{ng} \mathrm{g}^{-1}$. Casini et al. (2018) reported $\mathrm{Hg}$ concentrations in the range of $210-3,220$ $\mathrm{ng} \mathrm{g}^{-1}$ in scutes of loggerhead turtle, with CCL in the range of $20-78 \mathrm{~cm}$, in the Mediterranean Sea. Results from species, such as Lepidochelys kempii, that exhibit a similar diet to C. caretta, also showed a large variability of $\mathrm{Hg}$ concentrations in the carapace. L. kempii from the Gulf of California studied by Presti et al. (1999) and from the Massachusetts coast studied by Innis et al. (2008), showed total-Hg concentration varying from 41.3 to $7,486 \mathrm{ng} \mathrm{g}^{-1}$ and 48 to $1,058 \mathrm{ng} \mathrm{g}^{-1}$, respectively.

Unfortunately, there is no reported measured concentration of methyl- $\mathrm{Hg}$ in the carapace of C. caretta, making impossible comparison with other areas. Day et al. (2005), however, estimated methyl-Hg based on total $\mathrm{Hg}$ content suggesting concentrations from 5 to $220 \mathrm{ng} \mathrm{g}^{-1}$ ). Compared to other species, however, the average methyl$\mathrm{Hg}$ concentrations found in $C$. caretta scutes from Bahia were much lower than those found in carapace fragments of 86 individuals of C. mydas from South China by Ng et al. (2018) (10 to $570 \mathrm{ng}$ $\mathrm{g}^{-1}$; average $90 \mathrm{ng} \mathrm{g}^{-1}$ ).

The variability of $\mathrm{Hg}$ concentrations found in $C$. mydas, differently of $C$. caretta, is related to a major shift in diet of that species from pelagic carnivore to benthic herbivore, which is also strongly correlated with size. Thus, studies with green turtles $(C$. mydas) found negative relationships between size and $\mathrm{Hg}$ in kidney and muscle tissues (Sakai et al. 1995, Godley et al. 1999, McKenzie et al. 1999) as well as in scutes (Bezerra et al. 2012), with juveniles exhibiting higher $\mathrm{Hg}$ concentrations than adults, reflecting the carnivorous diet of juveniles.

The $\delta^{15} \mathrm{~N}$ and $\delta^{13} \mathrm{C}$ signatures of scutes $(7.4 \pm$ $2.5 \%$ and $-16.7 \pm 5.4 \%, \mathrm{n}=9$; for $\delta^{15} \mathrm{~N}$ and $\delta^{13} \mathrm{C}$ respectively) suggests a high trophic level of the loggerhead turtles from Bahia, agreeing with the results found in carapace fragments of this species by Revelles et al. (2007) in the Mediterranean and Zanden et al. (2014) in the Florida coast, USA. Unfortunately, the stable isotope composition of carapaces are not enough for a proper characterization of food web position, since the isotopic turnover rate for different type of tissue may influence the isotopic concentrations that these tissues may reflect, such as suggested by Vander Zanden et al. (2015).

A very interesting finding is that the $\mathrm{Hg}$ concentrations of these nine individuals ranged from 10.1 to $1,672 \mathrm{ng} \mathrm{g}^{-1}$, with no statistically significant correlation with $\delta^{15} \mathrm{~N}$, showing that although allocated at the same trophic level, $\mathrm{Hg}$ concentrations varied by at least 3 orders of magnitude and that, at least in the carapace, the concentrations of total-Hg or methyl-Hg are not influenced by the trophic level. Thus, for a species that is considered carnivorous, the concentrations of $\mathrm{Hg}$ in carapace fragments did not agree with its type of feeding. The lack of a sample of individuals with a smaller size did not allow to determine if there is some type of change in the trophic level of $C$. caretta.

Organisms of higher trophic levels have large distribution areas, and thus have larger feeding ranges than organisms at lower trophic levels (Atwell et al. 1998). Consequently, in the higher trophic levels, individuals of the same species may present fairly large ranges of $\mathrm{Hg}$ concentration, due to consumption of preys with different $\mathrm{Hg}$ content as shown for other large live, wide distributed species such as tunas (Lacerda et al. 2017). In addition, there are morphological factors and keratin composition of the carapace that may affect the degree of $\mathrm{Hg}$ deposition (Day et al. 2005). Mattei et al. (2015), found that the concentrations of some metals can be influenced by the ossification process, showing differences in concentrations that are found in the loggerhead turtle carapace. Reptile scutes are subdivided into various patterns, shapes, thickness 
and degree of overlap, factors that could influence the concentrations of total-Hg and methyl-Hg (Toni et al. 2007).

\section{CONCLUSIONS}

The $\mathrm{Hg}$ found in carapace fragments in adult females of loggerhead turtle, showed a wide variation, as previously found in the same species in different areas of the world. In the case of methyl-Hg, the concentrations were lower than those found in the few studies using carapace fragments. The isotopic composition of $\delta^{15} \mathrm{~N}$ and $\delta^{13} \mathrm{C}$ suggests that the individuals sampled belong to a similar and high trophic level, but isotope concentrations do not present any type of relation with the $\mathrm{Hg}$ content. Diet, morphology and chemical composition of the carapace would be factors to be evaluated in future studies, to determine the degree of influence they exert on the accumulation of this element. However, with the results found in the present study, it is still not possible to suggest the use of carapace fragments of $C$. caretta as a tool for environmental biomonitor of $\mathrm{Hg}$.

\section{ACKNOWLEDGMENTS}

The author would like to thank the Coordenação de Aperfeiçoamento de Pessoal de Nivel Superior (CAPES) for the financial support for the development of this project. Special thanks to the team of the Coastal Biogeochemistry Laboratory for the support in handling the equipment, processing and analysis of the samples, and to the team of the Marine Turtle Conservation Project (TAMAR Project) for the support in the field work. Moises F. Bezerra is funded by Conselho Nacional de Desenvolvimento Científico e Tecnológico (CNPq - Brasil) doctoral scholarship (proc. 202788/20148). Carlos Eduardo de Rezende is a member of the FEC initiative (https://www.futureearthcoasts.org/ regional-engagement-partners/).

\section{AUTHOR CONTRIBUTIONS}

CABR, MFB and LDL conceived the study and were responsible for the sampling, analysis, and writing of the manuscript. CER performed the nitrogen and carbon stable isotopes analyses and the discussion of the results, WRB performed the methyl-Hg analyses and the discussion of the results.

\section{REFERENCES}

ATWELL L, HOBSON KA AND WELCH HE. 1998. Biomagnification and bioaccumulation of mercury in an arctic marine food web: insights from stable nitrogen isotope analysis. Can J Fish Aquat Sci 55: 1114-1121.

BERGERON CM, BODINOF CM, UNRINE JM AND HOPKINS WA. 2010. Bioaccumulation and maternal transfer of mercury and selenium in amphibians. Environ Toxicol Chem 29: 989-997.

BEZERRA MF, LACERDA LD, COSTA BGB, LIMA EHSM. 2012. Mercury in the sea turtle Chelonia mydas (Linnaeus, 1958) from Ceara coast, NE Brazil. An Acad Bras Cienc 84: 123-128.

BEZERRA MF, LACERDA LD, LIMA EHSM AND MELO MTD. 2013. Monitoring mercury in green sea turtles using keratinized carapace fragments (scutes).Marine Pollut Bull 77(1-2): 424-427.

BEZERRA MF, LACERDA LD, REZENDE CE, FRANCO MAL, ALMEIDA MG, MACÊDO GR, PIRES TT, ROSTÁN G AND LOPEZ GG. 2015. Food preferences and $\mathrm{Hg}$ distribution in Chelonia mydas assessed by stable isotopes. Environ Pollut 206: 236-246.

BISINOTI MC AND JARDIM WF. 2004. O comportamento do metilmercúrio (metilHg) no ambiente. Química Nova 27: 593-600.

BJORNDAL KA. 1997. Foraging ecology and nutrition of sea turtles. In: Lutz PL and Musick JA (Eds), The Biology of Sea Turtles. CRC Press, Boca Raton, FL, p. 199-231.

BOLTEN AB. 2003. Active swimmers - passive drifters: the oceanic juvenile stage of loggerheads in the Atlantic system. Loggerhead Sea Turtles. Smithson. Books, Washington DC, p. 63-78.

CAMACHO M, OROS J, BOADA LD, ZACCARONI A, SILVI M, FORMIGARO C AND LUZARDO OP. 2013. Potential adverse effects of inorganic pollutants on clinical parameters of loggerhead sea turtles (Caretta caretta): results from a nesting colony from Cape Verde, West Africa. Marine Environ Red 92: 15-22.

CASINI S ET AL. 2018. First ecotoxicological assessment of Caretta caretta (Linnaeus, 1758) in the Mediterranean Sea using an integrated nondestructive protocol. Sci Total Environ 631-632: 1221-1233. 
CITAC. 2002. Cooperation on international trace ability in analytical chemistry. Eurachem. Guide to quality in analytical chemistry: An aid to accreditation, $57 \mathrm{p}$.

DAY RD, CHRISTOPHER SJ, BECKER PR AND WHITAKER DW. 2005. Monitoring mercury in the loggerhead sea turtle, Caretta caretta. Environ Sci Technol 39: 437-446.

DODD KC. 1988. Synopsis of the biological data on the loggerhead sea turtle Caretta caretta (Linnaeus 1758), US Fish and Wildlife Service.

EHSANPOUR M, AFKHAMI M, KHOSHNOOD R AND REICH KJ. 2014. Determination and maternal transfer of heavy metals $(\mathrm{Cd}, \mathrm{Cu}, \mathrm{Zn}, \mathrm{Pb}$ and $\mathrm{Hg})$ in the Hawksbill sea turtle (Eretmochelys imbricata) from a nesting colony of Qeshm Island, Iran. Bull Environ Contam Toxicol 92: 667-673.

FRICK MG, WILLIAMS KL, BOLTEN AB, BJORNDAL KA AND MARTINS HR. 2009. Foraging ecology of oceanicstage loggerhead turtles Caretta caretta. Endanger. Species Res 9: 91-97.

GODLEY BJ, THOMPSON DR AND FURNESS RW. 1999.

Do heavy metal concentrations pose a threat to marine turtles from the Mediterranean Sea? Mar Pollut Bull 38: 497-502.

GRAY JS. 2002. Biomagnification in marine systems: The perspective of an ecologist. Mar Pollut Bull 45: 46-52.

GUIRLET E, DAS K AND GIRONDOT M. 2008. Maternal transfer of trace elements in leatherback turtles (Dermochelys coriacea) of French Guiana. Aquat Toxicol 88: 267-276.

HONG YS, KIM YM AND LEE KE. 2012. Methylmercury exposure and health effects. J Prev Med Public Health 45(6): 353.

HOPKINS BC, WILLSON JD AND HOPKINS WA. 2013. Mercury Exposure is Associated with Negative Effects on Turtle Reproduction. Environ Sci 47: 2416-2422.

INNIS C, TLUSTY M, PERKINS C, HOLLADAY S, MERIGO C AND WEBER ES. 2008. Trace Metal and Organochlorine Pesticide Concentrations in Cold-Stunned Juvenile Kemp's Ridley Turtles (Lepidochelys kempii) from Cape Cod, Massachusetts. Chelonian Conserv Biol 7: 230-239.

IUCN. 2018. The IUCN Red List of Threatened Species, Version 2017-3. <www.iucnredlist.org>. Downloaded on 30 April 2018.

KIDD KA, HESSLEIN RH, FUDGE RJP AND HALLARD KA. 1995. The Influence of Trophic Level as Measured by $\delta^{15} \mathrm{~N}$ on Mercury Concentrations in Freshwater Organisms. Water Air Soil Pollut 80: 1011-1015.

LACERDA LD AND MALM O. 2008. Mercury Contamination in Aquatic Ecosystems: an Analisys of the Critical Areas. Estud Avançados 22: 173-190.
LACERDA LD, GOYANNA F, BEZERRA MF AND SILVA GB. 2017. Mercury Concentrations in Tuna (Thunnus albacares and Thunnus obesus) from the Brazilian Equatorial Atlantic Ocean. Bull Environ Contam Toxicol 98: 149-155.

MACKAY D AND FRASER A. 2000. Bioaccumulation of persistent organic chemicals: mechanisms and models. Environ Pollut 110: 375-391.

MARCOVALDI MÂ, LOPEZ GG, SOARES LS, LIMA EHSM, THOMÉ JCA AND ALMEIDA AP. 2010. Satellite-tracking of female loggerhead turtles highlights fidelity behavior in northeastern Brazil. Endanger. Species Res 12: 263-272.

MATTEI D, VESCHETTI E, D'ILIO S AND BLASI MF. 2015. Mapping elements distribution in carapace of Caretta caretta: A strategy for biomonitoring contamination in sea turtles? Mar Pollut Bull 98: 341-348.

MCKENZIE C, GODLEY BJ, FURNESS RW AND WELLS DE. 1999. Concentrations and patterns of organochlorine contaminants in marine turtles from Mediterranean and Atlantic waters. Mar Environ Res 47: 117-135.

MEYERS-SCHÖNE L AND WALTON B. 1994. Turtles as Monitors of Chemical Contaminants in the Environment. Rev Environ Contam Toxicol SE 3(135): 93-153.

NG CKY, LAM JCW, ZHANG XH, GU HX, LI TH, YE MB AND LAM IKS. 2018. Levels of trace elements, methylmercury and polybrominated diphenyl ethers in foraging green turtles in the South China region and their conservation implications. Environ Pollut 234: 735-742.

PETERSON BJ AND FRY B. 1987. Stable isotopes in Ecosystem Studies. Annu Rev Ecol Syst 18: 293-320.

PUGH RS AND BECKER PR. 2001. Sea Turtle Contaminants: A Review with Anotated Bibliography (No. NIST Interagency/Internal Report (NISTIR)-6700).

PRESTI SM, HIDALGO ARS, SOLLOD AE AND SEMINOFF AA. 1999. International Journal of Turtle and Tortoise Research. Chelonian Conserv Biol 3(3): 531-533.

REVELLES M, CARDONA L, AGUILAR A, BORRELL A, FERNÁNDEZ G AND FÉLIX MS. 2007. Stable C and N isotope concentration in several tissues of the loggerhead sea turtle Caretta caretta from the western Mediterranean and dietary implications. Sci Mar 71: 87-93.

SAKAI H, ICHIHASHI H, SUGANUMA H AND TATSUKAWA R. 1995. Heavy metal monitoring in sea turtles using eggs. Mar Pollut Bull 30: 347-353.

SAKAI H, SAEKI K, ICHIHASHI H, SUGANUMA H, TANABE S AND TATSUKAWA R. 2000. Speciesspecific distribution of heavy metals in tissues and organs of loggerhead turtle (Caretta caretta) and green turtle (Chelonia mydas) from Japanese coastal waters. Mar Pollut Bull 40: 701-709.

SCHNEIDER L, EGGINS S, MAHER W, VOGT RC, KRIKOWA F, KINSLEY L, EGGINS SM AND DA 
SILVEIRA R. 2015. An evaluation of the use of reptile dermal scutes as a non-invasive method to monitor mercury concentrations in the environment. Chemosphere 119: 163-170.

SCHNEIDER L, MAHER W, GREEN A AND VOGT RC. 2013. Mercury contamination in reptiles: an emerging problem with consequences for wild life and human health. Mercury: Sources Aplications and Health Impacts. Nova Science Publishers, Inc., Hauppauge, New York, USA, 173-232.

SHANKER G, SYVERSEN T AND ASCHNER M. 2003. Astrocyte-mediated methylmercury neurotoxicity. Biol Trace Elem Res 95(1): 1-10.

TAYLOR VF, CARTER A, DAVIES C AND JACKSON BP. 2011. Trace-level automated mercury speciation analysis. Anal Methods 3: 1143-1148.

TOMAS J, AZNAR FJ AND RAGA J. 2001. Feeding ecology of the loggerhead turtle Caretta caretta in the western Mediterranean. Hippocampus 255: 525-532.

TONI M, DALLA VALLE L AND ALIBARDI L. 2007. Hard (beta) keratins in the epidermis of reptiles: Composition, sequence, and molecular organization. J Proteome Res 6: 3377-3392.
UNEP. 2013. Global Mercury Assessment 2013: Sources, Emissions, Releases, and Environmental Transport. Unep 42.

US EPA - US ENVIRONMENTAL PROTECTION AGENCY. 2000. Guidance for assessing chemical contaminant data for use in fish advisories. Vol. 1: Fish Sampling and Analysis. EPA 823-B-00-007. Office of Science and Technology Office of Water US Environmental Protection Agency Washington, DC.

VANDER ZANDEN, MJ, CLAYTON MK, MOODY EK, SOLOMON CT AND WEIDEL BC. 2015. Stable isotopes turnover and half-life in animal tissues: a literature synthesis. PloS One 10(1): e0116182.

ZANDEN HB, VANDER TUCKER AD, BOLTEN AB, REICH KJ AND BJORNDAL KA. 2014. Stable isotopes comparison between loggerhead sea turtle tissues. Rapid Commun. Mass Spectrom 28: 2059-2064.

\section{SUPPLEMENTARY MATERIAL}

Table SI: Size, total-Hg, Methyl-Hg, \%Methyl-Hg, $\delta{ }^{13} \mathrm{C}$ and $\delta$ ${ }^{15} \mathrm{~N}$ concentrations of nesting loggerhead turtles from Praia do Forte, northern Bahia. 